\title{
The Clinical Significance of Epidermal Growth Factor Receptor (EGF-R) in Human Breast Cancer: A Review on 5232 Patients*
}

\author{
J. G. M. KLIJN, P. M. J. J. BERNS, P. I. M. SCHMITZ, AND J. A. FOEKENS
}

Department of Medical Oncology (J.G.M.K., P.M.J.J.B., J.A.F.), Division of Endocrine Oncology, and Department of Statistics (P.I.M.S.), The Dr. Daniel den Hoed Cancer Center, P.O. Box 5201, 3008 AE Rotterdam, The Netherlands.

I. Introduction

II. Analytical Review Method

III. Results

A. EGF-R measurement and positivity

B. Relationship with other prognostic factors

1. Relationship with steroid receptor status

2. Relationship with age or menopausal status

3. Relationship with tumor size

4. Relationship with lymph node status and recurrences

5. Relationship with histology

6. Relationship with tumor differentiation and grade

7. Relationship with tumor ploidy

8. Relationship with parameters for cellular proliferation

9. Relationship with oncogenes

10. Relationship with other growth factor or peptide hormone receptors

11. Relationship with membrane-bound tissue plasminogen activator

C. Relationship with prognosis and survival

1. Relationship with relapse-free and overall survival

2. Relationship with response to endocrine and chemotherapy

IV. Summary

V. Discussion and Conclusions

\section{Introduction}

$\mathrm{E}$ PIDERMAL growth factor (EGF) is a 53-aminoacid polypeptide (mol wt $6.045 \mathrm{~K}$ ) that can influence proliferation and differentiation of a wide variety of cells (1-6). EGF as well as transforming growth factor- $\alpha$ (TGF- $\alpha$ ), both of which can activate EGF receptor

* Supported by Grant RRTI 88-9 from the Dutch Cancer Society. Address requests for reprints and all correspondence to: Dr. J. G. M. Klijn, M.D., Ph.D., Division Endocrine Oncology, Dr. Daniel den Hoed Cancer Center, Groene Hilledijk 301, 3075 EA Rotterdam, The Netherlands.
(EGF-R), are probably produced locally in many tissues as local growth factors rather than as systemic hormones. There is evidence that EGF plays a role in carcinogenesis and that the EGF-stimulated growth regulatory system (apart from that of benign cells) is also involved in proliferation of malignant cells (3). Cellular events are induced by EGF via its cell membrane receptor (EGF$\mathrm{R})$. The EGF-R is a $170 \mathrm{~K}$ glycoprotein that can be divided into an extracellular domain binding EGF or TGF- $\alpha$, a short transmembrane domain, and an intracellular domain carrying tyrosine kinase activity (7). This intracellular domain shows close sequence homology with the c-erbB-2 and with neu (8), the rat homolog of c-erbB-2 oncogene. Increased expression of the EGF$\mathrm{R}$ gene has been found in a variety of tumors, generally indicating a more aggressive behavior of cancers compared to those with low or normal expression (9-10) although this association is not invariant (11). EGF-R has been identified by several methods including radioligand binding assays, autoradiography, immunocytohistochemistry, immunoenzymatic assays, and measurement of EGF-R transcripts.

EGF can stimulate the growth of normal mammary epithelium and human breast cancer cells in vitro (12, 13). Receptors for EGF have been demonstrated on several breast cancer cell lines, especially on estrogen receptor (ER)-negative tumor cells, and in human primary tumors and metastases $(4,13,14)$. At present there is no agreement on the clinical relationships and prognostic value of EGF-R in human breast cancer. Therefore, the objective of this review is to examine the clinical associations reported with EGF-R and breast cancer in a large series of publications including those from our group.

\section{Analytical Review Method}

The source of the articles for this review was the computerized Medline/EBSCO data-base. By such ex- 
tensive review of the literature we selected all papers reporting relevant data on one or more clinical aspects of EGF-R in breast cancer. Most studies on prognostic factors such as EGF-R concern pilot studies $(<150$ patients), sometimes followed by more definitive studies by the same investigators (15). Several groups published more than one paper on this subject. Comparing the results of different groups of investigators, for each separate parameter, we have used the most representative series of patients reported in the most recent paper from each group containing the largest series of patients. Ultimately we found data on EGF-R status in tumors of 5232 patients reported by 40 different groups of investigators. With respect to some clinical relationships we combined the results of relevant studies, giving more weight to larger studies, in order to confirm significant relationships suspected in smaller individual studies. With respect to the relationship between EGF-R levels and prognosis as published by nine different groups of investigators, we have chosen to summarize these results in descriptive terms in view of the great differences in their procedural and statistical methods, chosen cut-off values for EGF-R positivity, and patient characteristics.

\section{Results}

\section{A. EGF-R measurement and positivity}

Several methods for identifying EGF-R in human breast cancer have been applied including ligand binding assays $(14,16-54)$, autoradiography (55-59), immunocytohistochemistry/immunoenzymatic assays $(22,25,39$, $43,60-70)$, measurement of EGF-R transcripts (71-74), or EGF-R associated phosphotyrosine kinase activity (75) (Table 1). At present, there is no agreement on how best to define EGF-R positivity. Apart from different techniques, different cut-off levels have been used resulting in a wide variety of reported EGF-R positivity incidence ranging from 14-91\% (Table 1). With Scatchard analysis the reported dissociation constant $\left(\mathrm{K}_{\mathrm{d}}\right)$ values varied from $0.2-4.6 \mathrm{nM}$. Some authors $(25,51,54)$ report a good correlation between Scatchard analysis and single saturation dose ("two-point") assays. With respect to tumor EGF-R content, median values were reported between 1.1 and $40 \mathrm{fmol} / \mathrm{mg}$ membrane protein, while levels of individual tumors ranged from $0-3600 \mathrm{fmol} / \mathrm{mg}$ protein (Table 1). In fact, while significant specific binding of EGF (41) and phosphotyrosine kinase activity (75) was shown in $91 \%$ of tumors, a high level of EGF-R determined by Scatchard analysis was present in only about a third of all tumors (41). EGF-R gene amplification is rare, occurring in $0-14 \%$ of breast cancers $(71,76$, 77); however, EGF-R transcripts are demonstrable in $46-51 \%$ of primary tumors (71-74).

In $2500(48 \%)$ of 5232 tumors investigated by 40 dif- ferent study groups, EGF-R status was assessed as positive (Table 2). This percentage of $48 \%$ does not clearly differ from the mean (45\%) of the EGF-R positivities reported by these individual study groups (Table 2). When comparing the results of different techniques it is striking to note that the average EGF-R positivity showed less difference between the respective techniques used, varying from $42 \%$ for immunological methods to $45 \%, 46 \%$, and $48 \%$ for the radioligand binding assay, autoradiography, and measurement of EGF-R transcripts, respectively (Table 2). Only the single study detecting EGF-R associated kinase activity showed $91 \%$ positivity. There appears to be a close correlation between biochemical and immunological methods of detection of EGF-R (22, 25, 36, 43, 64). Grimaux et al. (64) and Koenders et al. (53) demonstrated no difference in results after either short- or long-term storage of tumors or membranes, respectively.

\section{B. Relationship with other prognostic factors}

1. Relationship with steroid receptor status. In contrast to two initial studies $(14,16)$ showing only a tendency to a negative relationship and one immunohistochemical study (66) of EGF-R, at least 28 different groups have reported a negative relationship between EGF-R and ER levels irrespective of the measuring technique used (Table 3). Interestingly, this was true despite great differences in reported ER-positive rates ranging from $34-82 \%$. In general, EGF-R positivity was observed in $29-91 \%$ (mean: $59 \%$ ) of ER-negative and in $4-51 \%$ (mean: 29\%) of ER-positive tumors reported by 21 different laboratories $(14,21,26,35,37-39,41,43,44,47$, $48,50,52-54,61,64,66,67,71)$.

With respect to the progesterone receptor (PR), most groups (12 of 19) have reported a negative relationship between EGF-R and PR levels (Table 3). In PR-negative tumors EGF-R positivity ranged from $23-91 \%$ (mean $51 \%$ ) and in PR-positive tumors from 6-55\% (mean $32 \%$ ) $(14,35,37-39,41,50,53,64,66,67,71)$. In summary, mean EGF-R positivity is twice as high in ER or PRnegative tumors $(59-51 \%)$ as compared to ER or PRpositive tumors (29-32\%).

With respect to the ER-regulated proteins ER-D5 and P24, Horne et al. (78) failed to demonstrate any significant relationship between these proteins and either EGF$\mathrm{R}$ or ER status.

Finally, although an association between EGF-R and total protein kinase $\mathrm{C}$ determined by phorbol-ester binding was not observed, Wyss et al. (31) demonstrated a negative relationship between total protein kinase $\mathrm{C}$ levels and steroid receptor levels in human primary breast cancer.

2. Relationship with age or menopausal status. Nine 
groups of investigators have studied the relationship between age and tumor EGF-R levels. Seven groups (14, $33,35,39,41,44,54,64)$ found no correlation between age and EGF-R, while two groups $(31,47)$ reported a negative relationship. Grimaux et al. $(39,64)$ made similar observations for both the biochemical and immuno- logical EGF-R assays. With respect to menopausal status, Sainsbury et al. (24) reported $45 \%$ and $30 \%$ EGF-R positivity in premenopausal and postmenopausal patients, respectively. Six other groups found no relationship between menopausal status and EGF-R levels (20, $35,39,41,44,66)$.

TABLE 1. EGF-R positivity in primary breast cancers measured by radioligand binding assay (RBA), autoradiography (AUT), immunocytochemistry or immunohistochemistry (IH), immunoenzymetric assay (IEMA), EGF-R transcripts (mRNA), and EGF-R associated phosphotyrosine kinase activity (PKA)

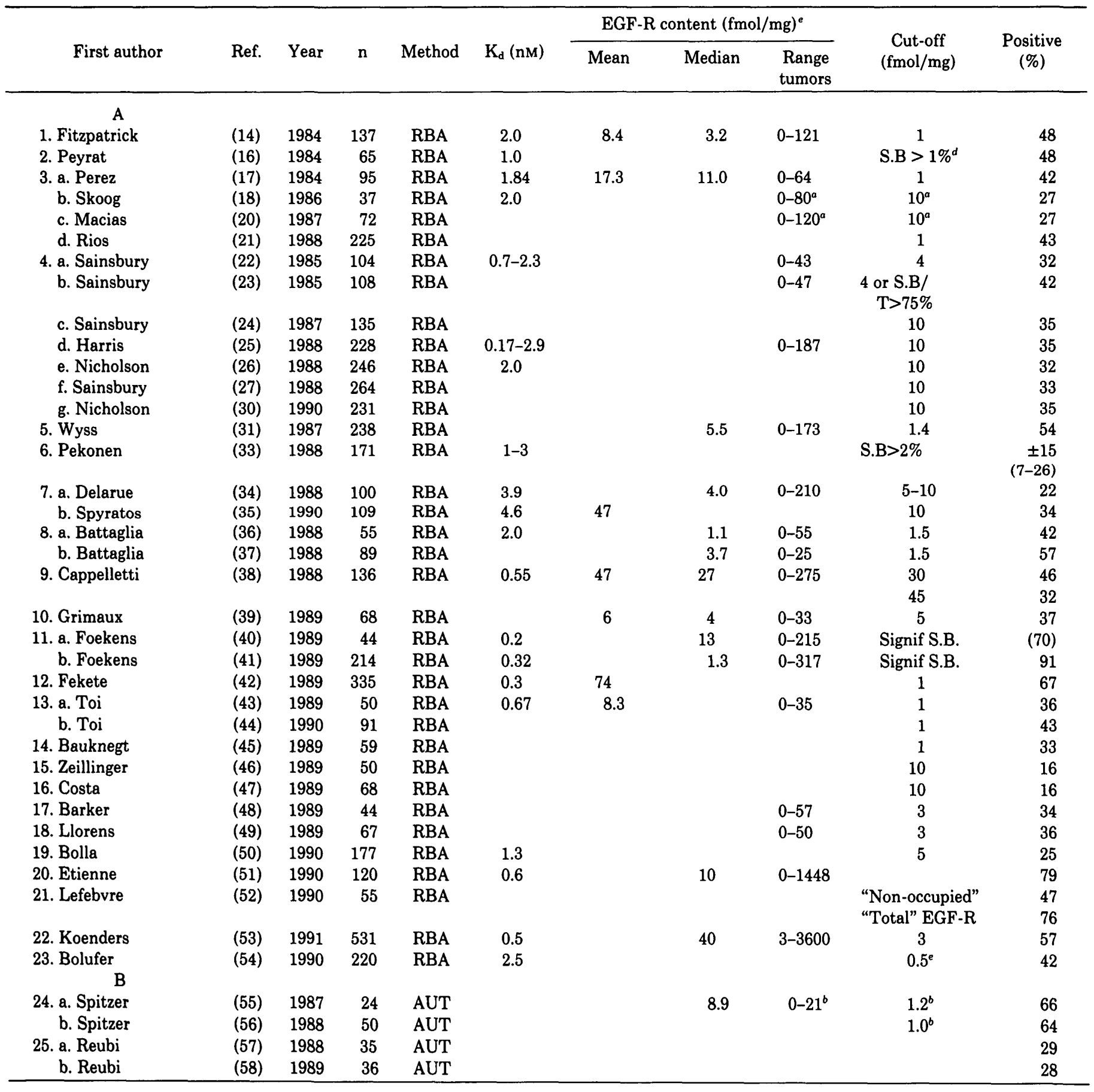


TABLE 1. Continued

\begin{tabular}{|c|c|c|c|c|c|c|c|c|c|c|}
\hline First author & Ref. & Year & $\mathrm{n}$ & Method & $\mathrm{MoAb}$ & Mean & Median & Range & $\begin{array}{c}\text { Cut-off } \\
\text { (fmol/mg) }\end{array}$ & $\begin{array}{c}\text { Positive } \\
\text { tumors (\%) }\end{array}$ \\
\hline $\mathrm{C}$ & & & & & & & & & & \\
\hline 26. a. Sainsbury & $(22)$ & 1985 & & I.H. & EGF-R1 & & & $0-3+$ & & $\begin{array}{l}\text { Correlated } \\
\text { with RBA }\end{array}$ \\
\hline b. Harris & $(25)$ & 1988 & 48 & I.H. & EGF-R1 & & & $0-3+$ & & 48 \\
\hline 29. Betta & $(62)$ & 1989 & 54 & I.H. & EGF-R1 & & & $0-3+$ & & 65 \\
\hline 30. Toi & (43) & 1989 & 50 & I.H. & EGF-R1 & & & $0-2+$ & $\geq 1+$ & 34 \\
\hline 31. Möller & (63) & 1989 & 197 & I.H. & EGF-R1 & & & $0-2+$ & $\geq 1+$ & 34 \\
\hline 32. Grimaux & $(64)$ & 1990 & $220-280$ & IEMA & EGF-R1 & 18 & 13 & $0-100$ & $\geq 20 \mathrm{fmol} / \mathrm{mg}$ & $\begin{array}{r}33 \text { correlated } \\
\text { with RBA }\end{array}$ \\
\hline & & & & & EGF-R528 & & & & & \\
\hline 36. Kommoss & (69) & 1990 & 55 & I.H. & & & & & & 60 \\
\hline 37. Hainsworth & $(70)$ & 1991 & 71 & I.H. & EGF-R1 & & & $0-4+$ & & 17 \\
\hline $\mathrm{D}$ & & & & & & & & & & \\
\hline 38. Guerin & $(71)$ & 1989 & 221 & EGF-R mRNA & & & & & & 46 \\
\hline 39. Coombes & $(73)$ & 1990 & 107 & EGF-R-mRNA & & & & & & 51 \\
\hline 40. Baugnet-Mahieu & $(75)$ & 1990 & 134 & EGF-R PKA & & & & & & 91 \\
\hline
\end{tabular}

${ }^{a}$ Atomoles/ $\mu \mathrm{g}$ DNA.

${ }^{b}$ Femtomoles/mg tissue protein.

' Femtomoles/mg homogenate.

${ }^{d}$ S.B., Specific binding.

${ }^{e}$ Femtomoles/mg membrane protein.

3. Relationship with tumor size. Fourteen groups (20-21, $33,35,39,41,44,47,50,54,61,62,66,67,70$ ) have found no significant correlation between tumor size and EGF$\mathrm{R}$ levels. On the other hand, Sainsbury and associates (24) and Harris and Nicholson (25) reported a significant positive correlation between EGF-R and increasing tumor size. In addition, Spitzer et al. (56) found higher EGF-R levels in larger tumors $(>4 \mathrm{~cm})$. In contrast, Cappelletti et al. (38) observed that tumors larger than 3 cm were mostly EGF-R-negative, while smaller tumors $(<3 \mathrm{~cm})$ were almost equally distributed among the EGFR-positive and -negative subsets. Bolla et al. (50) and our group (41) found a tendency to higher EGF-R levels in T1 tumors when compared to T2 and T3 tumors, respectively. Thus only two $(25,56)$ of 17 study groups found a positive correlation between tumor size and EGF-R levels, while three others $(38,41,50)$ found a trend toward a negative relationship.

4. Relationship with lymph node status and recurrences. Reports on the relationship between EGF-R and lymph node status are contradictory. EGF-R relationship to nodal status can be expressed in different ways, i.e. 1) EGF-R positivity or levels in primary tumors correlated with number of lymph nodes involved by metastases, or 2) EGF-R positivity or levels measured in lymph node metastases compared with those measured in the primary tumors.

Sainsbury et al. (24) observed that EGF-R positivity in primary tumors is higher in patients with nodal involvement $(\mathrm{N}+)$ as compared to node-negative $(\mathrm{N}-)$ patients (55\% vs. $30 \%)$. Battaglia et al. (37) also reported a higher incidence in $\mathrm{N}+$ patients $(77.7 \%)$ than in $\mathrm{N}-$ patients (25.7\%). In addition, Bolufer et al. (54) found that nodal involvement correlated significantly with EGF-R status only in the ER+ tumor subgroup, but not in all tumors. In noninflammatory breast cancer Guérin et al. (71) found that the presence of EGF-R transcripts increased linearly with the number of positive lymph nodes. Hainsworth et al. (70) also found that EGF-R expression correlated with the number of involved lymph nodes. However, 15 groups found no significant correlation between EGF-R positivity in the primary tumor and the presence or number of axillary lymph node metas- 
TABLE 2. Mean EGF-R positivity by method in 40 different series of patients

\begin{tabular}{|c|c|c|c|c|c|}
\hline \multirow[t]{2}{*}{ Method } & \multirow{2}{*}{$\begin{array}{c}\text { No. of series } \\
(n)\end{array}$} & \multicolumn{2}{|c|}{ A. Patients } & \multicolumn{2}{|c|}{$\begin{array}{c}\text { B. EGF-R } \\
\text { positivity (\%) }\end{array}$} \\
\hline & & $\mathbf{n}$ & EGF-R+ & Mean & Range \\
\hline RBA & 23 & 3533 & $1723(49 \%)$ & 45 & $(15-91)$ \\
\hline Autoradiography & 2 & 86 & $42(49 \%)$ & 46 & $(28-64)$ \\
\hline Immunologically & 12 & 1151 & $451(39 \%)$ & 42 & $(14-65)$ \\
\hline EGF-R transcripts & 2 & 328 & $162(49 \%)$ & 48.5 & $(46-51)$ \\
\hline $\begin{array}{l}\text { EGF-R associated } \\
\text { kinase activity }\end{array}$ & 1 & 134 & $122(91 \%)$ & 91 & \\
\hline Total & 40 & 5232 & $2500(48 \%)$ & $45 \%$ & $(14-91)$ \\
\hline
\end{tabular}

Part A, Mean EGF-R positivity based on all individual patients included, giving more importance to larger series of patients than to smaller series.

Part B, Mean and range of EGF-R positivity based on the reported percentages for each separate series (irrespective the size of the series).

tases $(16,21,33,35,39,41,44,47,50,54,56,61,62,66$, 67). Grimaux et al. (39), however, reported that EGF-R was often elevated in the tumors of patients with less than four involved nodes, while Toi et al. (43) observed a positive correlation between EGF-R status and lymphatic vessel invasion. Spitzer et al. (56) observed higher EGF-R levels in the primary tumors of patients with lymph node metastases than in those primary tumors that lacked lymph node metastases $(8.1$ vs. $3.4 \mathrm{fmol} / \mathrm{mg}$, respectively), but this difference was not significant ( $P$ $<0.1$ ).

With respect to EGF-R positivity and EGF-R levels in lymph node metastases or recurrences $v s$. those in the primary tumors, Sainsbury et al. (22) reported $71 \%$ positivity in the lymph node metastases vs. $32 \%$ in the primary tumors. Macias et al. (19) also reported a significantly higher incidence of EGF-R positivity in lymph node metastases $(52 \%)$ or recurrences $(47 \%)$ than in primary tumors (25-7\%). Battaglia et al. (37) observed a median increase in EGF-R levels of $157 \%$ (range 27$590 \%$ ) in lymph node metastases; overall, EGF-R levels were significantly $(P<0.05)$ higher in metastases than in primary tumors (median: $3.7 \mathrm{vs} .2 .2 \mathrm{fmol} / \mathrm{mg}$ protein). Grimaux et al. (39) also found higher mean EGF-R levels in tumor-bearing nodes as compared to primary tumors (10.37 vs. $6.03 \mathrm{fmol} / \mathrm{mg}$ protein), but this difference did not appear to be statistically significant. These authors did observe a significant correlation between EGF-R levels in the nodes and primary tumors of 10 patients investigated.

In conclusion, nine $(19,24,37,39,43,54,56,70,71)$ of 20 studies showed a positive relationship between EGF-R and lymph node status, but in only five $(19,24$, $36,70,71$ ) of these was this relationship statistically significant.
5. Relationship with histology. Fitzpatrick et al. (14) reported that $\left[{ }^{125}\right.$ I]EGF binding approached a significant correlation with the percentage of malignant breast cells. Using immunohistochemistry Möller et al. (63) showed EGF-R expression in ductal, lobular, and myoepithelial cells, but only occasionally in stroma cells. In addition, Battaglia et al. (37) reported that the stroma was completely unreactive to monoclonal antibodies against EGF-R, while only malignant cells stained positive. Using autoradiography Spitzer et al. (55) also observed that fat and connective tissues were almost devoid of any EGF binding. On the other hand, Tsutsumi et al. (68) found that in a few carcinomas EGF-R positivity localized only to stromal cells. EGF-R levels may be decreased, increased, or unchanged in cancer cells as compared with their normal counterpart (3). Pekonen et al. (33) reported no difference in EGF-R binding in normal tissue from that found in cancer tissue, and the only normal tissue with high EGF binding was adjacent to a carcinoma.

Generally speaking, there seems to be no clear relationship between EGF-R and histological type of breast cancer (Table 4). A higher EGF-R positivity was found in ductal carcinomas as compared to lobular carcinomas by Skoog et al. (18) (36\% us. 0\%), Sainsbury et al. (27) ( $34 \%$ vs. $21 \%$ ), and Costa et al. (47) (23\% vs. $6 \%$ ), while Wrba et al. (61) (58\% vs. 57\%), Toi et al. (44) (43\% vs. $33 \%$ ), and Grimaux et al. (64) (31\% vs. $42 \%$ ) found no significant difference in EGF-R positivity between ductal and lobular carcinomas, respectively. Spitzer et al. (55) also found no significant difference in EGF-R levels between ductal and lobular carcinomas (9.7 versus 7.4 $\mathrm{fmol} / \mathrm{mg}$ ). EGF-R has been demonstrated in most subtypes of primary breast cancer $(18,27,61,64)$, although positivity of EGF-R seems somewhat lower in mucoid and tubular tumors (20\%), which appears in agreement with the reported better long-term survival attributed to these well differentiated tumor types (79). As summarized in Table 4, EGF-R-positivity was frequently found in medullary carcinomas (88\%), but Möller et al. (63), using immunohistochemistry, reported finding EGF-R in only one of seven patients with medullary breast tumors. EGF binding correlated with number of mitoses $(55,56)$ especially in node-positive patients $(56)$, and EGF-R transcripts were more frequently detected in inflammatory breast cancer $(58 \%)$ than in noninflammatory breast cancer (39\%) (71). It is interesting to note that Reubi and Torhorst (57) reported high EGF-R density in necrotic tumor areas.

6. Relationship with tumor differentiation and grade. Seventeen groups studied the relationship between EGF-R and tumor differentiation and grade. Ten different groups $(23-25,33,34,39,44,50,54,56,63,64,70)$ 
TABLE 3. Relationship between steroid receptors (ER, PR) and EGF-R

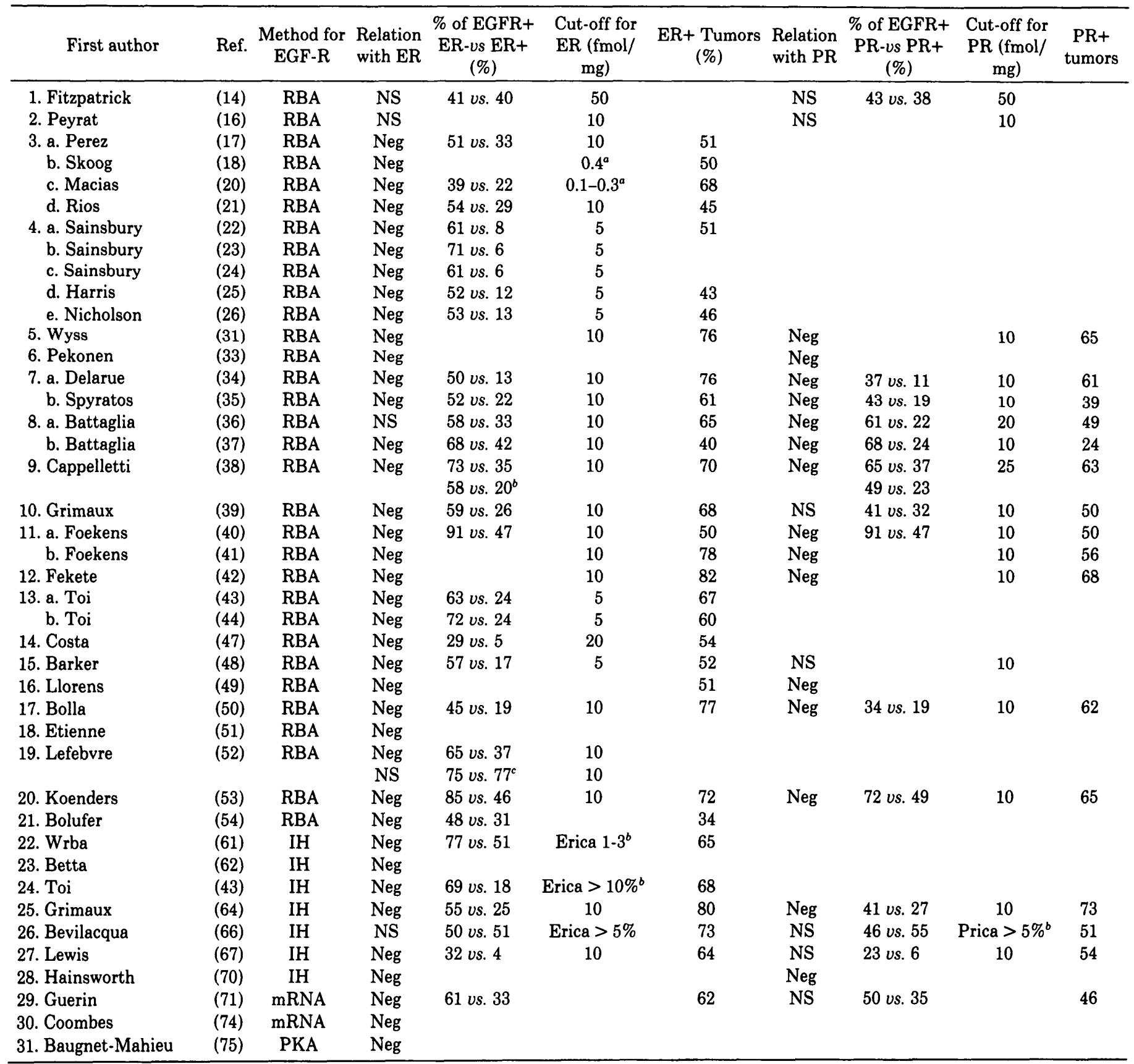

See Table 1 for patient number, EGF-R cut-off levels and EGF-R positivity.

RBA, Radioligand binding assay; IH, immunocytohistochemistry; mRNA, EGF-R transcripts; PKA, EGF-R associated phosphotyrosine kinase activity; NS, not significant.

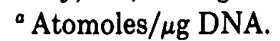

${ }^{b}$ Other cut-off levels for EGF-R (see Table 1).

c "Total" EGF-R.

demonstrated a positive relationship between EGF-R and grade, poorly differentiated tumors showing a higher percentage of EGF-R positivity and higher EGF-R levels. In contrast, eight groups $(16,35,41,60-62,66,67)$ did not find a significant correlation between these two parameters. Bolufer et al. (54) found a positive relation- ship within the ER-negative, but not the ER-positive subgroup.

7. Relationship with tumor ploidy. Seven groups $(20,35$, $39,47,60,64,65)$ studied the relationship between EGF$\mathrm{R}$ and tumor ploidy, also known as the tumor DNAindex or content as determined by flow cytometry. Only 
TABLE 4. The EGF-R in different histological subtypes of mammary tumors

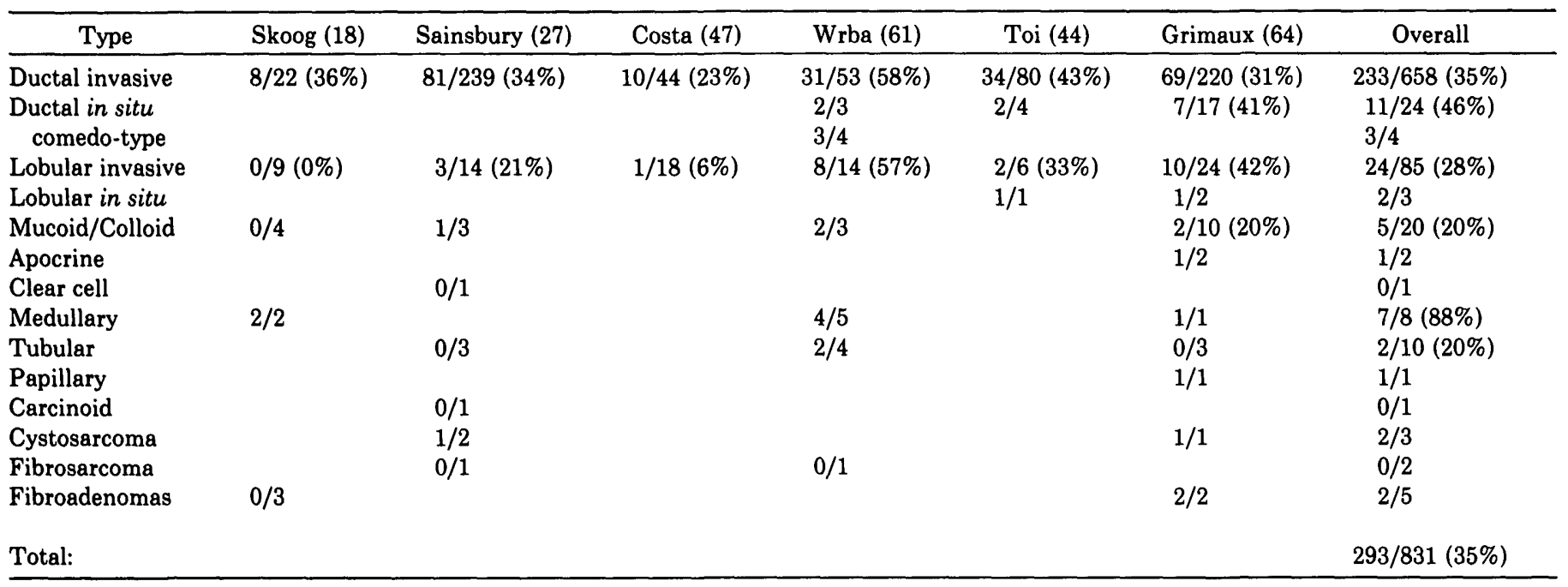

N.B. Spitzer et al. (55): mean EGF-R ductal ca $(\mathrm{n}=16)=9.7 \mathrm{fmol} / \mathrm{mg}>\mathrm{NS}$ mean EGF-R lobular ca $(\mathrm{n}=18)=7.4 \mathrm{fmol} / \mathrm{mg}$

Walker and Camplejohn (60) found a significant correlation between these two parameters while six groups did not find any significant relationship (Table 5). All series showed a higher incidence of EGF-R positivity in aneuploid tumors (mean $36 \%$; range $21-50 \%$ ) than in diploid tumors (mean 13\%; range 0-29\%). Taking the absolute numbers reported in five studies together (Table 5), we calculated the presence of EGF-R positivity in 88 of 253 aneuploid tumors (35\%) vs. only 17 of 114 diploid tumors (15\%) $[P<0.0001$, method of Der Simonian and Laird (79a), 1986]. Thus, most investigators did not find any significant correlation between EGF-R and DNA-index probably due to the small number of patients in their series of patients, but the overall incidence of EGF-R may be 2 to 3 times higher in aneuploid than in diploid tumors.

8. Relationship with parameters for cellular proliferation. Nine groups studied the relationship of EGF-R with thymidine labeling index $(n=1)$, S-phase fraction $(n=$ $3)$, Ki-67 index $(n=4)$, or mitotic activity $(n=1)$. Macias et al. (20) found EGF-R positivity in $33 \%$ of 39 tumors with a high $(>5 \%)$ labeling index vs. $13 \%$ of 16 tumors with a low $(<5 \%)$ index, but this difference was not statistically significant. Walker and Camplejohn (60) demonstrated a close correlation $(P<0.01)$ between the presence of EGF-R and high ( $>14 \%$ ) S-phase content in 48 tumors investigated, but Costa et al. (47) and Grimaux et al. (64) did not find a significant correlation in series of 28 and 60 tumors, respectively. With respect to Ki-67 immunoreactivity, Toi et al. (44) found that in 27 tumors the average proportion of $\mathrm{Ki}$-67-stained cells in EGF-Rpositive tumors was $25.4 \%$ in contrast to $8.6 \%$ in EGF-
$\mathrm{R}$-negative ones $(P<0.01)$. Three other groups $(61,62$, 66 ) were not able to demonstrate a significant correlation between these two parameters in series of 88,54 , and 134 patients, respectively. Finally, Spitzer et al. $(55,56)$ reported a significant positive correlation between the number of mitoses counted under light microscopy and EGF binding, but this association was mainly in $\mathrm{N}+$ patients (56). In sum, only three $(44,55,60)$ of the nine studies reported any correlation between EGF-R and parameters relating to high cellular proliferation, but these series were all relatively small.

9. Relationship with oncogenes. Although EGF-R is structurally homologous to the c-erbB-2/neu oncogene (8) and both appear to be negatively correlated with steroid receptor status, there is no agreement on a (potential) positive association between EGF-R and c-erbB-2/HER2/neu. Hainsworth et al. (70) and Marx et al. (80) did find a positive correlation between expression of EGF-R and c-erbB-2, but other reports $(30,46,81,82)$ indicate the opposite or no relationship. Tsutsumi et al. (68) observed a single case of breast cancer that overexpressed both EGF-R and neu in reciprocal immunohistochemical staining patterns, indicating that EGF-R positive cells were also not overexpressing the neu protein. Zeillinger et al. (46) investigated the relationship between HER-2 amplification, steroid receptors, and EGF-R in 291 primary breast cancers. HER-2 gene amplification was demonstrated in $18 \%$ of the tumors, in $14 \%$ of ER-positive and in $28 \%$ of ER-negative tumors. In this large series no association between HER-2 amplification and either EGF-R or androgen receptor was observed.

Hainsworth et al. (70) showed that EGF-R membrane 
TABLE 5. Relationship between EGF-R status and DNA pattern

\begin{tabular}{|c|c|c|c|}
\hline Authors (Ref.) & $\frac{\text { Absolute numbers EGF-R+ }}{\text { Aneuploid } v s . \text { diploid }}$ & \multicolumn{2}{|c|}{ \% EGF-R+ } \\
\hline 1. Macias (20) & $15 / 46$ vs. $3 / 24$ & 33 vs. 13 & NS \\
\hline 3. Spyratos (35) & $29 / 78$ vs. $9 / 31$ & 37 vs. 29 & NS \\
\hline 4. Grimaux (RBA) (39) & $14 / 38$ vs. $0 / 16$ & 37 vs. 0 & NS \\
\hline 5. Grimaux (IEMA) (64) & $11 / 53$ vs. $4 / 33$ & 21 vs. 12 & NS \\
\hline Total & $88 / 253(35 \%)$ us. $17 / 114(15 \%)$ & $\overline{\mathrm{x}}=36 \%$ vs. $13 \%$ & $P<0.0001^{\circ}$ \\
\hline
\end{tabular}

${ }^{a}$ Method of Der Simonian and Laird (79a).

staining was a much stronger prognostic indicator than c-erbB-2 product or ras $\mathrm{p} 21$ staining; in contrast, Wright et al. (82), applying multivariate analysis, demonstrated that both lymph node status and c-erbB-2 oncoprotein staining were more important prognosticators than EGF$\mathrm{R}$ as measured by ligand binding assay.

Nicholson et al. (30) reported that patient prognosis based on neu was independent of EGF-R status and that the combination of neu positivity with EGF-R increased the prognostic power, showing an apparently additive effect in predicting a more aggressive course of disease. This is in agreement with recent experimental data showing that combinations of moderate levels of expression of EGF receptors and c-erbB-2, which are not individually capable of cell transformation, can together produce fully transformed cells $(83,84)$.

EGF-R was barely detectable in ras transfected cells, while myc transfected cells were much more sensitive to the growth-stimulatory effects of EGF without an increase in EGF-R levels as compared to nontransfected cells $(6,25)$.

10. Relationship with other growth factor or peptide hormone receptors. In agreement with the results of Pekonen et al. (33) we did not find an association between EGF$\mathrm{R}$ and insulin-like growth factor I receptor levels (41). In addition, Peyrat et al. (16) and Fekete et al. (42) demonstrated no relationship with tumor PRL-R concentrations and [D-Trp ${ }^{6}$-LHRH binding sites, respectively.

Reubi et al. (59) discussed an inverse relationship between the presence of somatostatin receptors (SS-R) and EGF-R measured by autoradiography. They demonstrated the presence of EGF-R in only 18 of $71(25 \%)$ SS-R-positive primary breast cancers $(57,58)$. The tissue location of SS-R did not coincide with that of EGF-R (59). Whereas SS-R were located on tumor tissue, EGF$R$ were often seen on adjacent normal lobules and ducts. On the other hand, using a biochemical assay for EGF$\mathrm{R}$, we did not observe a significant correlation between
EGF-R and SS-R (41). Also, Fekete et al. (42) found no relationship between EGF-R and SS-R both measured by Scatchard analysis.

11. Relationship with membrane-bound tissue plasminogen activator. There is a large amount of evidence that plasminogen activators (PA) are involved in tumor invasion and metastasis. Harris and Nicholson (25) divided 43 breast cancers into ER+/EGF-R-, ER-/EGF-R+, and ER-/EGF-R- subgroups. While there was no significant difference in total PA between these groups, tissue PA (tPA) was significantly lower in ER-/EGF-R+ tumors. The lack of PA appeared to be associated with an aggressive group of tumors, and it was suggested that EGF-R might have a role in suppressing tissue PA secretion (25).

\section{Relationship with prognosis and survival}

1. Relationship with relapse-free (RFS) and overall survival (OS). Thus far nine different groups (20-21, 24, 30, $32,35,39,41,44,67,72-74)$ have reported on the relationship between EGF-R and survival. The size of the series of patients investigated ranged from 55-376 with EGF-R positivity in $14-55 \%$ (Table 6 ). The median (12-66 months) and maximal (30-96 months) follow-up showed great differences. In the majority of the studies systemic adjuvant therapy was given in a number of patients, mostly in the node-positive group. Using univariate analysis, five groups $(21,24,30,32,39,67)$ found a significant relationship between EGF-R status and RFS or OS at a certain time point of follow-up (Table 6). This finding was confirmed in two of three studies using multivariate analysis.

Sainsbury et al. (24) indicated that by multivariate analysis EGF-R status was the most important variable in predicting RFS and OS in lymph node-negative patients and the second most important variable in lymph node-positive patients. RFS and OS were significantly worse for patients with EGF-R-positive tumors as compared to patients with EGF-R-negative tumors. The best 


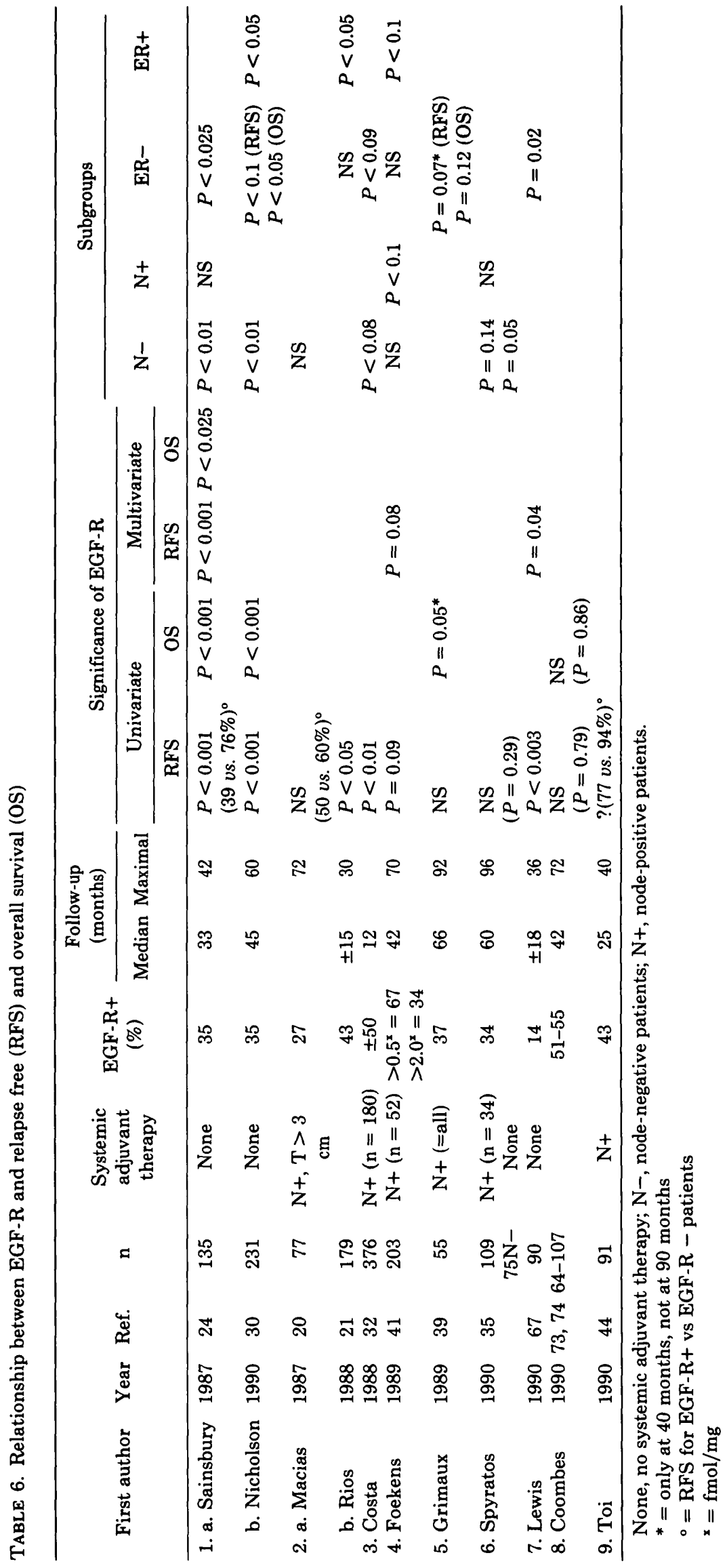


discriminative effect was found in subgroups with lymph node-negative or ER-negative tumors. In contrast, we found only a tendency $(P 0.09)$ for a negative relationship between EGF-R and RFS (41). Macias et al. (20) initially reported a 6 -yr relapse rate in 10 of $20(50 \%)$ patients with EGF-R positive tumors vs. 22 of $52(40 \%)$ patients with EGF-R negative tumors, but this difference was not statistically significant. They later observed a significant relationship in a larger series of patients with shorter follow-up interval (21). Grimaux et al. (39) reported a nearly significant prognostic value $(P 0.051)$ when overall survival curves were analyzed at 40 months follow-up [which is comparable to the follow-up duration in the study of Sainsbury (24)], but EGF-R failed to predict long-term outcome. Spyratos et al. (35) also found that EGF-R had no predictive value for long-term outcome. Two other studies, by Costa et al. (32) and Lewis et al. (67), reported a significant prognostic relationship, but their patient follow-up period was very short. Toi et al. (44) observed a relapse in $23 \%$ of EGF-R-positive patients and only $6 \%$ in EGF-R-negative patients, but the statistical significance in this was not indicated. Coombes et al. (74), measuring transcripts for EGF-R, found no relationship with relapse-free survival.

In contrast to Sainsbury et al. (24) we found the best discriminative effects of EGF-R to be in lymph nodepositive or ER-positive patient subsets (41). Lewis et al. (67), in agreement with Sainsbury's results (24), found a significant discriminative effect of EGF-R in the ERnegative subgroup of patients, but the other groups of investigators $(20,21,32,35,39,41)$ did not make such an observation, although a tendency to such relationship was present in two $(32,39)$ of these studies (Table 6). Rios et al. (21) found only a significant discriminative effect of EGF-R in ER-positive patients. EGF-R+/ERpatients showed the poorest and EGF-R-/ER+ patients the best survival probability $(21,39)$ due, no doubt, to the better discriminative effect of EGF-R in ER+ patients (21). Lymph node status and steroid receptor content appeared to be better prognosticators than EGF$R(20,41)$, but in a subgroup of 55 node-positive patients Grimaux et al. (39) reported that EGF-R was the only biological parameter to reach statistical significance in predicting for early death. Macias et al. (20) also reported that within node- positive patients, EGF-R had prognostic value that was not present within the node-negative patient subgroup. Furthermore, Spyratos et al. (35) and Costa et al. (32) found no significant prognostic effect in node-negative patients. However, when, in the former study (35), patients receiving prior adjuvant therapy were excluded, EGF-R appeared as the only significant prognostic variable $(P 0.05)$. For those studies $(24,30,67)$ in which systemic adjuvant therapy had not been given, the best discriminative effect of EGF-R was observed.
In summary, five $(21,24,32,39,67)$ of nine study groups have shown significant prognostic value for EGF$\mathrm{R}$ and survival after short-term (1-4 yr) follow-up, while three $(20,39,41)$ of five groups $(20,35,39,41,74)$, having a maximal follow-up interval of at least $6 \mathrm{yr}$, found only a tendency $(0.10>P>0.05)$ associating EGF-R with survival. It appears that EGF-R-positive tumors are more prone to first relapses at visceral sites $(24,28,44$, 54), while EGF-R-negative tumors more often recur in the bone.

2. Relationship with response to endocrine and chemotherapy. Nicholson et al. $(28,30)$ reported that expression of EGF-R is associated with lack of response to endocrine therapy in recurrent breast cancer. Only $8 \%$ of EGF-Rpositive tumors showed an objective response to firstline treatment with tamoxifen in metastatic breast cancer while $30 \%$ of EGF-R-negative tumors responded ( $P$ $<0.05$ ). Only one of 28 EGF-R +/ER- tumors achieved an objective response. Patients with EGF-R-positive primary tumors showed more rapid disease progression after start of first-line endocrine therapy than those with EGF-R-negative tumors. In one preliminary study, Harris (29) observed that in 25 patients, who received firstline single chemotherapy with mitoxantrone, there was no correlation between EGF-R status and response to therapy, time to tumor progression, or survival.

\section{Summary}

EGF-R positivity was shown to be present in 2500 (48\%) of 5232 breast tumors in 40 different series of patients. The mean of the percentages of EGF-R positivity in the individual series reported by these 40 different groups of investigators is $45 \%$ (range $14-91 \%$ ). Overall there are generally no clear differences between results obtained by radioligand binding assays, immunological methods, autoradiography, and measurement of EGF-R transcripts although the mean percentage of EGF-Rpositive tumors determined by immunological methods tends to be somewhat lower. Nearly all studies indicate a negative relationship between EGF-R and steroid receptor status (28 of 31 studies for ER, 12/19 for PR) showing that EGF-R positivity is twice as high in ER or PR- negative tumors compared to ER or PR-positive tumors ( $50-60 \%$ vs. $30 \%)$. With regard to other prognostic factors the majority of investigators (10/18) also reported a significant (positive) correlation with tumor grade, but only a minority found a significant relationship between EGF-R status and patient age (2/9), menopausal status $(1 / 7)$, histological type $(3 / 7)$, tumor size $(2 / 17)$, nodal status $(5-9 / 20)$, ploidy $(1 / 7)$, or proliferation indices (3/9). No relationship was observed with tumor insulin-like growth factor I receptor, PRL receptor (PRL-R), and LHRH receptor (LHRH-R) status, but an 
inverse relationship between EGF-R and somatostatin receptor may be present. However, it has to be stressed that the series in which the relationship between EGF$\mathrm{R}$ status and other prognostic factors were investigated, contained relatively few patients (mostly $<100$ ). Therefore, when larger groups of patients are investigated, more significant relationships may be observed, especially with respect to nodal status, tumor ploidy, and proliferation indices. In fact, we calculated the presence of EGF-R positivity overall in $35 \%$ of 253 aneuploid tumors vs. in only $15 \%$ of 114 diploid tumors $(P<$ 0.0001 ). In addition most studies observed a trend, if no significant correlation, between higher EGF-R levels in tumors with the highest percentages of S-phase or Ki-67 expression. With regard to relapse-free and overall survival, five of nine different groups of investigators showed significant prognostic value of EGF-R after short-term (1- to 4-yr) follow-up, indicating that patients with EGF-R-positive tumors have a poor prognosis. However, three of five groups with a maximal follow-up of at least $6 \mathrm{yr}$ found only a tendency for any relationship between EGF-R status and long-term outcome.

\section{Discussion and Conclusions}

The efficacy and cost effectiveness of adjuvant systemic therapy in women with primary breast cancer are important subjects of current debate $(85,86)$. More selective use of chemotherapy to maximize the benefit to individual patients may be possible with refinements in risk stratification and better assessment of the patients' risk preferences. There are numerous prognostic factors reported for primary breast cancer (see review in Ref. 87). EGF-R is a more recent tumor marker whose prognostic value has been well studied but remains controversial. This may be due to differences in techniques used for EGF-R measurements or cut-off levels chosen for EGF-R positivity. However, we could find no clear differences between the results obtained by radioligand binding assay, immunological methods, autoradiography, or measurement of EGF-R transcripts. The slighty lower EGF-R positivity using immunological methods might by explained by a lower assay sensitivity than for ligand binding assays, accounting for EGF-R-positive tumors by ligand binding assay that are negative by immunohistochemical analysis (25). In some cases EGF-R was undetectable by ligand binding or immunochemistry but could be detected by enhancement of autophosphorylation with EGF (25).

Despite the great variation in cut-off levels for EGF$R$ positivity, nearly all investigators report a negative relationship between tumor EGF-R status and steroid receptor levels. Although ER levels are positively correlated with age $(87,88)$, there is an absence of such a relation between EGF-R and age or menopausal status, as observed by nearly all investigators. We also found a negative relationship between cytosolic EGF/TGF- $\alpha$-like activities [growth factors that can influence the number of detectable EGF-R $(89,90)]$ and steroid receptor levels in breast cancer (40). Macias et al. (91) showed higher TGF $\alpha$ contents in metastatic than in primary breast cancer, but, in contrast to our findings, did not find a correlation between tumor TGF $\alpha$ content and ER levels. Measuring gene transcripts of EGF, ER, and PR, Dotzlaw et al. (92) recently showed that EGF was more frequently detectable in ER or PR-positive tumors than in ER or PR-negative breast tumors. They also demonstrated a positive association between EGF messenger RNA and steroid receptor levels. However, Barrett-Lee et al. (72) and Coombes and co-workers $(73,74)$ observed no association between TGF $\alpha$ mRNA and survival.

The results correlating EGF-R status and RFS are very controversial: some groups have found a very close correlation, while others have found only a tendency or no significant relationship between these parameters. Comparing EGF-R status with previously validated prognostic indices, Hainsworth et al. (70) observed a significant association, but Lewis et al. (67) did not. Sainsbury et al. (24) found by multivariate analysis that EGF-R status was the most important variable in predicting RFS and OS in lymph node-negative patients and the second most important variable in lymph node-positive patients. Spyratos et al. (35) noted that although EGF$R$ status had overall no significant prognostic value, it was the only significant prognosticator in node-negative patients, while Lewis et al. (67) stated that EGF-R was the third most important prognosticator after nodal status and grade. However, with respect to subgroup analysis by nodal or ER status, there is no agreement on the best prognosticator and in which subgroup EGF-R status offers the most predictive power. The differences in results and conclusions might partly be due to differences in patient number, cut-off levels for both EGF-R and $\mathrm{ER}$, application of systemic adjuvant therapy, and duration of patient follow-up-generally concerns affecting the evaluation of other prognostic factors (15). In view of the prominent predictability value of EGF-R status in those series in which patients were not treated with adjuvant therapy, and the observed association between tumor EGF-R positivity and lack of response to endocrine therapy (but not to chemotherapy) in patients with metastatic disease, the overall influence of adjuvant systemic treatment on the prognostic power of EGF-R status has yet to be established (especially for long-term outcome).

Furthermore, it has to be stressed that the size of all reported series are generally small, ranging from 20 or 30 to a few hundred patients. Only three studies $(30,32$, 
41) included more than 200 patients. Furthermore, apart from assessment by $P$ values in univariate and multivariate analysis in relation to RFS and OS, the potential impact of a prognostic factor should preferably also be expressed by positive and negative predictive values and their differences. For example Nicholson et al. (30) report a $5 \mathrm{yr}$ RFS of approximately $20 \%$ (derived from the figure) for patients with EGF-R+ tumors (positive predictive value at $5 \mathrm{yr}$ ) and a $5 \mathrm{yr}$ RFS of $38 \%$ for patients with EGF-R-tumors (negative predictive value at $5 \mathrm{yr}$ of follow-up). The difference of these values (18\%) is a measure of the impact of the prognostic value of EGFR. Similarly, Foekens et al. (41) have shown a 5 yr RFS of approximately $43 \%$ and $67 \%$ for patients with low or high and intermediate EGF-R tumor values, respectively, thus a difference of $24 \%$. Unfortunately, in the other studies indicated in Table 6, it appears difficult to evaluate the prognostic value of EGF-R other than in terms of significant $P$ values. Therefore, to make definite conclusions about the relationships and predictive value of EGF-R status, larger confirmatory studies with longterm follow-up periods are warranted.

It would also be essential to have a standardized EGF$R$ assay. In view of the lack of a uniform method for EGF-R measurement and uniform criterion for positivity (cut-off point), the authors propose standardization of EGF-R assays. In this respect it is noteworthy to mention that the EORTC Receptor Study Group has recently declared the hydroxylapatite method as the method of choice to separate bound from free ligand (93). After minor modification, this HAP-assay adopts a membrane protein threshold of $0.2 \mathrm{mg} / \mathrm{ml}$ in order to avoid falsenegative results due to too low protein content (53). A clinically valuable significant cut-off level for positivity of EGF-R using this assay has yet to be determined by taking length of RFS and OS as endpoints. For smaller tissue samples or cytological samples, autoradiography or immunoassays may be used. Apart from the consensus reached by the EORTC Receptor Study Group to use HAP adsorption of EGF-R as a tool to separate bound from free ligand by low-speed centrifugation procedures, more work has to be done before the EGF-R assay will be completely standardized. Major aspects that need standardization include the membrane preparation to be used and the reference parameter on which to express EGF-R (e.g. protein, DNA, wet weight, or a membrane marker such as $5^{\prime}$-nucleotidase).

In view of the close similarity between EGF-R (cerbB-1) and HER2/neu (c-erbB-2) oncogene protein, it is interesting to compare the clinical relationships and prognostic value of these two membrane markers. For the EGF-R gene a great difference has been found between the incidence of gene amplification $(0-14 \%)$ ( 71 , 76,77 ) relative to protein (over)expression (about half of the patients), in contrast to HER2/neu in which there is a strong correlation between amplification and overexpression. Amplification and/or overexpression of the HER2/neu gene has been described in approximately $20 \%$ of breast tumors (range $8-64 \%$ ) (94-100). In our most recent update (100) of the literature, data encompassing a total of 11,408 breast tumors, we calculated a mean HER2/neu positive incidence of $20 \%$ without finding any significant difference between the incidence of amplification and overexpression. This means that EGF$\mathrm{R}$-positive tumors relate to a greater proportion ( $45 \%)$ of breast cancer patients than do HER2/neu positive tumors (20\%), which might suggest an advantage for the measurement of EGF-R as prognostic parameter. The prognostic value of HER2/neu amplification in breast cancer has been studied extensively since the initial report by Slamon et al. (101), showing that HER2/neu amplification is an independent prognostic factor in node-positive patients. Recent reviews (94-99) suggest that there is no association between elevated HER2/neu and patient age, only a tentative relationship with tumor grade, size, or nodal involvement, and an inverse association with steroid hormone receptors. There is no consensus on the independent prognostic power of HER2/neu to predict either RFS or OS. Most interestingly, these relationships and conclusions are similar and comparable to those described for EGF-R in this review. Few authors $(70,82)$ have compared the prognostic power of EGF-R and HER2/neu in the same study, and these show conflicting results (see Section B.9).

\section{Conclusions}

Based on 40 separate studies comprising 5232 patients, the mean percentage of EGF-R positivity reported in breast cancer is $45 \%$ (range $14-91 \%$ ).

Overall, there is no clear difference in results between radioligand binding assays, immunological methods, autoradiography, and measurement of EGF-R transcripts (mean EGF-R positivity for respective techniques ranging between $42-48 \%$ ), although EGF-R positivity by immunological methods tends to be lower.

In view of the lack of an uniform method for EGF-R measurement and uniform criterion for positivity (cutoff point), the authors propose standardization of EGF$R$ assays as established by the EORTC in order to employ such standard methods for clinical trials involving EGFR.

Correlations with other prognostic factors and with prognosis in lymph node-negative and positive disease can be made based on the current literature but will likely be more clear if such standard methodology is accepted, as occurred for ER and PR.

There is a negative correlation between EGF-R and 
steroid receptor (ER, PR) levels showing that EGF-Rpositivity is twice as high in ER- or PR-negative tumors than in ER- or PR-positive tumors ( $50-60 \%$ vs. $30 \%)$.

There is no relationship between EGF-R status and age or menopausal status.

There is no clear association between EGF-R and tumor size.

Some authors suggest that there is a higher incidence of EGF-R positivity for primary tumors in patients with nodal involvement or higher EGF-R levels in lymph node metastases/recurrences as compared to primary tumors, but other studies disagree.

There may be higher EGF-R positivity in ductal carcinomas than in lobular carcinomas, but this is not a uniform observation.

There is a likely association between high EGF-R levels and poor tumor differentiation and grade.

When the results of several studies are combined there appears to be an association between a higher (2- to 3fold) incidence of EGF-R positivity and aneuploid tumors as compared to diploid tumors.

A few studies indicate a positive correlation between EGF-R and higher rates of breast cancer proliferation.

There is no relationship between EGF-R and IGF-1$R, P R L-R$, or LHRH-R, but possibly an inverse relationship with SS-R.

There is little agreement on the prognostic value of EGF-R, with most studies indicating a tendency or weak association between EGF-R and RFS or OS. There is also no agreement on the subgroups of patients in which EGF-R may have a discriminative prognostic effect. The discriminatory effect of EGF-R status with respect to prognosis seems to decrease with long-term follow-up compared to short follow-up as previously shown and discussed by some authors $(88,102)$ for the ER status.

Patients with advanced disease and EGF-R-positive tumors respond less well to first-line endocrine treatment as compared to EGF-R-negative tumors, but the significance of this independence of ER status is unknown. There is no apparent relationship between EGF-R status and response to first-line chemotherapy, but this has not been well studied.

\section{Acknowledgment}

We would like to thank R. Kalkman, who prepared the manuscript.

\section{References}

1. Carpenter G, Cohen S 1979 Epidermal growth factor. Annu Rev Biochem 48:193

2. Carpenter G 1981 Epidermal growth factor. Handb Exp Pharmacol 57:90

3. Stoschek CM, King LE 1986 Role of epidermal growth factor in carcinogenesis. Cancer Res 46:1030

4. Fisher DA, Lakshmanan J 1990 Metabolism and effects of epidermal growth factor and related growth factors in mammals. Endocr Rev 11:418
5. Dickson RB, Lippman ME 1988 Control of human breast cancer by estogen, growth factors, and oncogenes. In: Lippman ME, Dickson RB (eds) Breast Cancer: Cellular and Molecular Biology. Kluwer Press, Boston, p 119

6. Dickson RB 1990 Stimulatory and inhibitory growth factors and breast cancer. J Steroid Biochem Mol Biol 37:795

7. Downward J, Parker P, Waterfield MD 1984 Autophosphorylation sites on the epidermal growth factor receptor. Nature 311:483

8. Bargmann CI, Hung M-C, Weinberg RA 1986 The neu oncogene encodes an epidermal growth factor receptor-related protein. $\mathrm{Na}$ ture 319:226

9. Neal DE, Bennett MK, Hall RR, Marsh C, Abel PD, Sainsbury JRC, Harris AL 1985 Epidermal-growth-factor receptors in human bladder cancer: comparison of invasive and superficial tumors. Lancet 1:366

10. Yasui W, Hata J, Yokozaki H, Nakatani H, Ochiai A, Ito $H$, Tahara E 1988 Interaction between epidermal growth factor and its receptor in progression of human gastric carcinoma. Int $J$ Cancer 41:211

11. Dazzi H, Hasleton PS, Thatcher N, Barnes DM, Wilkes S, Swindell R, Lawson RA 1989 Expression of epidermal growth factor receptor (EGF-R) in non-small cell lung cancer. Use of archival tissue and correlation of EGF-R with histology, tumour size, node status and survival. $\mathrm{Br} \mathrm{J}$ Cancer 59:746

12. Osborne CK, Hamilton B, Titus G, Livingston RB 1980 Epidermal growth factor stimulation on human breast cancer cells in culture. Cancer Res 40:2361

13. Fitzpatrick SL, LaChance MP, Schultz GS 1984 Characterization of epidermal growth factor receptor and action on human breast cancer cells in culture. Cancer Res 44:3342

14. Fitzpatrick SL, Brightwell J, Wittliff JL, Barrows GH, Schultz GS 1984 Epidermal growth factor binding by breast tumor biopsies and relationship to estrogen receptor and progestin receptor levels. Cancer Res 44:3448

15. McGuire WL 1991 Breast cancer prognostic factors. Editorial. J Natl Cancer Inst 83:154

16. Peyrat JP, Bonneterre J, VandeWalle B, Djiane J, Lefebvre J 1984 EGF receptors in human breast cancers; relations with hormone receptors. Ann Endocrinol (Paris) 45:412

17. Perez R, Pascual M, Macias A, Lage A 1984 Epidermal growth factor receptors in human breast cancer. Breast Cancer Res Treat 4:189

18. Skoog L, Macias A, Azavedo E, Lombardero J, Klintenberg C 1986 Receptors for EGF and oestradiol and thymidinekinase activity in different histological subgroups of human mammary carcinomas. Br J Cancer 54:271

19. Macias A, Azavedo E, Perez R, Rutquist LE, Skoog L 1986 Receptors for epidermal growth factor in human mammary carcinomas and their metastases. Anticancer Res 6:849

20. Macias A, Azavedo E, Hägerström T, Klintenberg C, Perez R, Skoog L 1987 Prognostic significance of the receptor for epidermal growth factor in human mammary carcinomas. Anticancer Res 7:459

21. Rios MA, Macias A, Perez R, Lage A, Skoog L 1988 Receptors for epidermal growth factor and estrogen as predictors of relapse in patients with mammary carcinoma. Anticancer Res 8:173

22. Sainsbury JRC, Sherbet GV, Farndon JR, Harris AL 1985 Epidermal-growth-factor receptors and oestrogen receptors in human breast cancer. Lancet 1:364

23. Sainsbury JRC, Malcolm AJ, Appleton DR, Farndon JR, Harris AL 1985 Presence of epidermal growth factor receptor as an indicator of poor prognosis in patients with breast cancer. J Clin Pathol 38:1225

24. Sainsbury JRC, Needham GK, Farndon JR, Malcolm AJ, Harris AL 1987 Epidermal-growth-factor receptor status as predictor of early recurrence of and death from breast cancer. Lancet 1:1398

25. Harris AL, Nicholson S 1988 Epidermal growth factor receptors in human breast cancer. In: Lippmann ME, Dickson RB (eds) Breast Cancer: Cellular and Molecular Biology. Kluwer Academic Publishers, Boston, $\mathrm{p} 93$

26. Nicholson S, Sainsbury JRC, Needham GK, Chambers P, Farndon JR, Harris AL 1988 Quantitative assays of epidermal growth 
factor receptor in human breast cancer: cut-off points of clinical relevance. Int J Cancer 42:36

27. Sainsbury JRC, Nicholson S, Angus B, Farndon JR, Malcolm AJ, Harris AL 1988 Epidermal growth factor receptor status of histological sub-types of breast cancer. Br J Cancer 58:458

28. Nicholson S, Sainsbury JRC, Halcrow P, Chambers P, Farndon JR, Harris AL 1989 Expression of epidermal growth factor receptors associated with lack of response to endocrine therapy in recurrent breast cancer. Lancet 1:182

29. Harris AL 1990 Epidermal growth factor receptor: a marker of early relapse in breast cancer: interactions with neu. Eur J Cancer 26:154 (Abstract 29)

30. Nicholson S, Wright C, Sainsbury JRC, Halcrow P, Kelly P, Angus B, Farndon JR, Harris AL 1990 Epidermal growth factor receptor (EGFr) as a marker for poor prognosis in node-negative breast cancer patients: neu and tamoxifen failure. J Steroid Biochem Mol Biol 37:811

31. Wyss R, Fabro D, Regazzi R, Borner C, Takahashi A, Eppenberger U 1987 Phorbol ester and epidermal growth factor receptors in human breast cancer. Anticancer Res 7:721

32. Costa S, Stamm H, Almendral A, Ludwig H, Wyss R, Fabbro D, Ernst A, Takahashi A, Eppenberger U 1988 Predictive value of EGF receptor in breast cancer. Lancet 2:1258

33. Pekonen F, Partanen S, Mäkinen T, Rutanen E-M 1988 Receptors for epidermal growth factor and insulin-like growth factor I and their relation to steroid receptors in human breast cancer. Cancer Res 48:1343

34. Delarue JC, Friedman S, Mouriesse H, May-Levin F, SanchoGarnier H, Contesso G 1988 Epidermal growth factor receptor in human breast cancers: correlation with estrogen and progesterone receptor. Breast Cancer Res Treat 11:173

35. Spyratos F, Delarue J-C, Andrieu C, Lidereau R, Champème MH, Hacène K, Brunet M 1990 Epidermal growth factor receptors and prognosis in primary breast cancer. Breast Cancer Res Treat $17: 83$

36. Battaglia F, Polizzi G, Scambia G, Rossi S, Panici PB, Iacobelli S, Crucitti F, Mancuso S 1988 Receptors for epidermal growth factor and steroid hormones in human breast cancer. Oncology $45: 424$

37. Battaglia F, Scambia G, Rossi S, Panici PB, Bellantrone R, Polizzi G, Querzoli P, Negrini R, Iacobelli S, Crucitti F, Mancuso S 1988 Epidermal growth factor receptor in human breast cancer: correlation with steroid hormone receptors and axillary lymph node involvement. Eur J Cancer Clin Oncol 24:1685

38. Cappelletti V, Brivio M, Miodini P, Granata G, Coradini B, Di Fronzo G 1988 Simultaneous estimation of epidermal growth factor receptors and steroid receptors in a series of 136 resectable primary breast tumors. Tumor Biol 9:200

39. Grimaux M, Romain S, Remvikos Y, Martin PM, Magdelénat H 1989 Prognostic value of epidermal growth factor receptor in node-positive breast cancer. Breast Cancer Res Treat 14:77

40. Foekens JA, Portengen H, Janssen M, Klijn JGM 1989 Insulinlike growth factor-1 receptors and insulin-like growth factor-1like activity in human primary breast cancer. Cancer 63:2139

41. Foekens JA, Portengen H, van Putten WLJ, Trapman AMAC, Reubi J-C, Alexieva-Figusch J, Klijn JGM 1989 Prognostic value of receptors for insulin-like growth factor 1, somatostatin, and epidermal growth factor in human breast cancer. Cancer Res 49:7002

42. Fekete M, Wittliff JL, Schally AV 1989 Characteristics and distribution of receptors for [D-TRP $]$-luteinizing hormone-releasing hormone, somatostatin, epidermal growth factor, and sex steroids in 500 biopsy samples of human breast cancer. J Clin Lab Anal 3:137

43. Toi M, Hamade Y, Nakamura T, Mukaida H, Suehiro S, Wada T, Toge T, Niimoto M, Hattori T 1989 Immunocytochemical and biochemical analysis of epidermal growth factor receptor expression in human breast cancer tissues: relationship to estrogen receptor and lymphatic invasion. Int $\mathrm{J}$ Cancer 43:220

44. Toi M, Nakamura T, Mukaida H, Wada T, Osaki A, Yamada H, Toge T, Niimoto M, Hattori T 1990 Relationship between epi- dermal growth factor receptor status and various prognostic factors in human breast cancer. Cancer 65:1980

45. Bauknegt T, Kohler M, Janz J, Pfleiderer A 1989 The occurrence of epidermal growth factor receptors and the charcterization of EGF-like factors in human ovarian, endometrial, cervical and breast cancer. J Cancer Res Clin Oncol 115:193

46. Zeillinger R, Kury F, Czerwenka K, Kubista E, Sliutz G, Knogler W, Huber J, Zielinski C, Reiner G, Jakesz R, Staffen A, Reiner A, Wrba F, Spona J 1989 HER-2 amplification, steroid receptors and epidermal growth factor receptor in primary breast cancer. Oncogene 4:109

47. Costa SD, Kaufmann M, Fabbro D, Tokus M, Feichter G, Klinge K, Bastert G 1989 Epidermal growth factor receptors and flowcytometry in primary breast cancer: relationship to hormone receptor and lymph node status. Geburtshilfe Frauenheilkd 49:375

48. Barker S, Panahy C, Puddefoot JR, Goode AW, Vinson GP 1989 Epidermal growth factor receptor and oestrogen receptors in the non-malignant part of the cancerous breast. Br J Cancer 60:673

49. Llorens MA, Bermejo MJ, Salcedo MC, Charro AL, Puente M 1989 Epidermal growth factor receptors in human breast and endometrial carcinomas. J Steroid Biochem 34:505

50. Bolla M, Chedin M, Souvignet C, Marron J, Arnould C, Chambaz E 1990 Estimation of epidermal growth factor receptor in 177 breast cancers: correlation with prognostic factors. Breast Cancer Res Treat 16:97

51. Etienne MC, Formento JL, Francoual M, Formento P, Fischel JL, Namer M, Frenay M, Milano G 1990 Epidermal growth factor receptor assay: validation of a single point saturation method in breast cancer. Eur J Cancer 26:181 (Abstract 139)

52. Lefebvre MF, Garin E, Falette N, Saez S 1990 Evaluation of epidermal growth factor receptor occupancy by EGF-like peptide in 55 breast and 42 non-breast tumor biopsies. Eur J Cancer 26:182 (Abstract 145)

53. Koenders PG, Beex LVAM, Geurts-Moespot A, Heuvel JJTM, Kienhuis CBM, Benraad TJ 1991 Epidermal growth factor receptor negative tumors are predominantly confined to the subgroup of estradiol receptor positive human primary breast cancer. Cancer Res 51:4544

54. Bolufer P, Miralles F, Rodriguez A, Vasquez C, Lluch A, GarciaConde J, Olmos T 1990 Epidermal growth factor receptor in human breast cancer: correlation with cytosolic and nuclear ER receptors and with biological and histological tumor characteristics. Eur J Cancer 26:283

55. Spitzer E, Grosse R, Kunde D, Schmidt HE 1987 Growth of mammary epithelial cells in breast-cancer biopsies correlates with EGF binding. Int J Cancer 39:279

56. Spitzer E, Koepke K, Kunde D, Grosse R 1988 EGF binding is quantitatively related to growth in node-positive breast cancer. Breast Cancer Res Treat 12:45

57. Reubi JC, Torhorst J 1988 EGF receptors in human breast cancer on viable and necrotic tumour cells. Breast Cancer Res Treat $12: 245$

58. Reubi JC, Torhorst J 1989 The relationship between somatostatin, epidermal growth factor, and steroid hormone receptors in breast cancer. Cancer 64:1254

59. Reubi JC, Waser B, Foekens JA, Klijn JGM, Lamberts SWJ, Laissue J 1990 Somatostatin receptor incidence and distribution in breast cancer using receptor autoradiography: relationship to EGF receptors. Int J Cancer 46:416

60. Walker RA, Camplejohn RS 1986 DNA flow cytometry of human breast carcinomas and its relationship to transferrin and epidermal growth factor receptors. J Pathol 150:37

61. Wrba F, Reiner A, Ritzinger E, Holzner JH 1988 Expression of epidermal growth factor receptors (EGFR) on breast carcinomas in relation to growth fractions, estrogen receptor status and morphological criteria: an immunohistochemical study. Pathol Res Pract 183:25

62. Betta PG, Robutti F, Spinoglio G, Bottero G 1989 Expression of epidermal growth factor receptor in human breast carcinoma and its correlation with morphological and biological features of tumours aggressiveness. Pathologica 81:425

63. Möller P, Mechtersheimer G, Kaufmann M, Moldenhauer G, 
Momburg F, Mattfeldt T 1989 Expression of epidermal growth factor receptor in benign and malignant primary tumours of the breast. Virchows Arch [Pathol Anat] 414:157

64. Grimaux M, Mady E, Remvikos Y, Laine-Bidron C, Magdelenat H 1990 A simplified immuno-enzymetric assay of the epidermal growth factor receptor in breast tumors: evaluation in 282 cases. Int $\mathrm{J}$ Cancer 45:255

65. Gasparini G, Santini G, Reitano M, Meli S, Bevilacqua P 1990 Relationship of the epidermal growth factor receptor (EGFR) with the growth fraction and the flowcytometric S-phase as cell kinetics parameters in human mammary carcinomas. Eur J Cancer 26:182 (Abstract 144)

66. Bevilacqua P, Gasparini G, Dal Fior S, Corradi G 1990 Immunocytochemical determination of epidermal growth factor receptor with monoclonal EGFR1 antibody in primary breast cancer patients. Oncology 47:313

67. Lewis S, Locker A, Todd JH, Bell JA, Nicholson R, Elston CW, Blamey RW, Ellis IO 1990 Expression of epidermal growth factor receptor in breast carcinoma. J Clin Pathol 43:385

68. Tsutsumi Y, Naber SP, DeLellis RA, Wolfe HJ, Marks PJ, McKenzie SJ, Yin S $1990 \mathrm{Neu}$ oncogene protein and epidermal growth factor receptor are independently expressed in benign and malignant breast tissues. Hum Pathol 21:750

69. Kommoss F, Colley M, Hart CE, Franklin WA 1990 In situ distribution of oncogene products and growth factor receptors in breast carcinoma:c-erbB-2 oncoprotein, EGFr, and PDGFr-bètasubunit. Mol Cell Probes 4:11

70. Hainsworth PJ, Henderson MA, Stillwell RG, Bennett RC 1991 Comparison of EGF-R, C-erbB-2 product and ras p21 immunohistochemistry as prognostic markers in primary breast cancer. Eur J Surg Oncol 17:9

71. Guérin M, Gabillot M, Mathieu M-C, Travagli J-P, Spielmann M, Andrieu N, Riou G 1989 Structure and expression of c-erb B2 and EGF receptor genes in inflammatory and non-inflammatory breast cancer: prognostic significance. Int $J$ Cancer 43:201

72. Barrett-Lee P, Travers M, Luqmani Y, Coombes RC 1990 Transcripts for transforming growth factors in human breast cancer: clinical correlates. Br J Cancer 61:612

73. Coombes RC, Murray P, Luqmani Y 1990 The prognostic significance of transcripts for transforming growth factor alpha and betà and epidermal growth factor receptor in primary breast cancer. Eur J Cancer 26:159 (Abstract 49)

74. Coombes RC, Barrett-Lee P, Luqmani Y 1990 Growth factor expression in breast tissue. J Steroid Biochem Mol Biol 37:833

75. Baugnet-Mahieu L, Lemaire M 1990 Expression of epidermal growth factor receptor and C-erb B-2 oncoprotein in human tumors. Eur J Cancer 26:181 (Abstract 138)

76. Ro J, North SM, Gallick GE, Hortobagyi GN, Gutterman JU, Blick M 1988 Amplified and overexpressed epidermal growth factor receptor gene in uncultured primary human breast carcinoma. Cancer Res 48:161

77. Lacroix H, Iglehart JD, Skinner MA, Kraus MH 1989 Overexpression of erbB-2 or EGF receptor proteins present in early stage mammary carcinoma is detected simultaneously in matched primary tumors and regional metastases. Oncogene 4:145

78. Horne GM, Angus B, Wright C, Needham G, Nicholson S, Harris AL, Innes B, Horne HW 1988 Relationships between oestrogen receptor, epidermal growth factor receptor, ER-D5, and P24 oestrogen regulated protein in human breast cancer. J Pathol 155:143

79. Dixon JM, Page DL, Anderson TJ, Lee D, Elton RA, Stewart HJ, Forrest APM 1985 Long-term survivors after breast cancer. Br J Surg 72:445

79a.Der Simonian R, Laird N 1986 Meta-analysis in clinical trials. Controlled Clinical Trials 7:177

80. Marx D, Schauer A, Reiche C, May A, Ummenhofer L, Reles A, Rauschecker H, Sauer R, Schumacher M 1990 C-erbB-2 expression in correlation to other biological parameters of breast cancer. $\mathrm{J}$ Cancer Res Clin Oncol 116:15

81. Bacus SS, Ruby SG, Weinberg DS, Chin D, Ortiz R, Bacus JW
$1990 \mathrm{Her}-2 /$ neu oncogene expression and proliferation in breast cancers. Am J Pathol 137:103

82. Wright C, Angus B, Nicholson S, Sainsbury JRC, Cairns J, Gullick WJ, Kelly P, Harris AL, Horne CHW 1989 Expression of C-erbB-2 oncoprotein: a prognostic indicator in human breast cancer. Cancer Res 49:2087

83. Kokai Y, Myers JN, Wada T, Brown VI, LeVea CM, Davis JG, Dobashi K, Green MI 1989 Synergistic interaction of p185c-neu and the EGF receptor leads to transformation of rodent fibroblasts. Cell 58:287

84. Gullick WJ $1990 \mathrm{New}$ developments in the molecular biology of breast cancer. Eur J Cancer 26:509

85. McGuire WL 1989 Adjuvant treatment of node-negative breast cancer. N Engl J Med 320:525

86. Hillner BE, Smith TJ 1991 Efficacy and cost effectiveness of adjuvant chemotherapy in women with node-negative breast cancer. A decision-analysis model. N Engl J Med 324:160

87. Klijn JGM, Foekens JA 1990 Prognostic factors in breast cancer. In: Goldhirsch A (ed) Endocrine Therapy of Breast Cancer IV. Monographs European School of Oncology. Springer-Verlag, Berlin, $\mathrm{p} 17$

88. Alexieva-Figusch J, van Putten WLJ, Blankenstein MA, Blonkvan der Wijst Klijn JGM 1988 The prognostic value and relationships of patient characteristics, progestin receptor, estrogen receptor, and site of relapse in primary and metastatic human breast cancer. Cancer 61:758

89. Kudlow JE, Cheung C-YM, Bjorge JD 1986 Epidermal growth factor stimulates the synthesis of its own receptor in a human breast cancer cell line. J Biol Chem 261:4134

90. Fernandez-Pol JA, Klos DJ, Hamilton PD 1989 Modulation of transforming growth factor alpha-dependent expression of epidermal growth factor receptor gene by transforming growth factor beta, triiodothyronine, and retinoic acid. J Cell Biochem 41:159

91. Macias A, Perez R, Hägerström T, Skoog L 1989 Transforming growth factor alpha in human mammary carcinomas and their metastases. Anticancer Res 9:177

92. Dotzlaw H, Miller T, Karvelas J, Murphy LC 1990 Epidermal growth factor gene expression in human breast cancer biopsy samples: relationship to estrogen and progesterone receptor gene expression. Cancer Res 50:4204

93. Benraad TJ, Foekens JA 1990 Hydroxyapatite assay to measure epidermal growth factor receptor in human primary breast tumours. Ann Clin Biochem 27:272

94. MaGuire HC, Greene MI 1989 The neu (c-erbB-2) oncogene. Semin Oncol 16:148

95. Gullick WJ 1990 The role of the epidermal growth factor receptor and the c-erbB-2 protein in breast cancer. Int $J$ Cancer [Suppl] $5: 55$

96. Clark GM, McGuire WL 1991 Follow-up study of HER-2/neu amplification in primary breast cancer. Cancer Res 51:944

97. Perren TJ 1991 C-erbB-2 oncogene as a prognostic marker in breast cancer. Br J Cancer 63:328

98. Berns PMJJ, Klijn JGM, Foeken JA 1992 Oncogene amplification in human breast and ovarian cancer. In: Spandidos DA (ed) Current Perspectives on Molecular and Cellular Oncology. JAI Press Ltd, London, in press

99. Berns PMJJ, Klijn JGM, van Staveren IL, Foekens JA 1992 HER-2/neu gene amplification in primary human breast cancer. In: Jonat W, Lönnig T (eds) Proceedings International Symposium on the Clinical and Scientific Relevance of HER-2/neu/ erbB2. Springer Verlag, Berlin, in press

100. Klijn JGM, Berns PMJJ, Bontenbal M, Alexieva-Figusch J, Foekens JA 1992 Clinical breast cancer, new developments in selection and endocrine treatment of patients. J Steroid Biochem Mol Biol, in press

101. Slamon DJ, Clark GM, Wong SG, Levin WJ, Ullrich A, McGuire WL 1987 Human breast cancer: correlation of relapse and survival with amplification of the HER2/neu oncogene. Science 235:177

102. Kinsel LB, Szabo E, Greene GL, Konrath J, Leight GS, McCarty Jr KS 1989 Immunocytochemical analysis of estrogen receptors as a predictor of prognosis in breast cancer patients: comparison with quantitative biochemical methods. Cancer Res 49:1052 